JOURNAL OF MENTAL SCIENCE, APRIL, 1929.

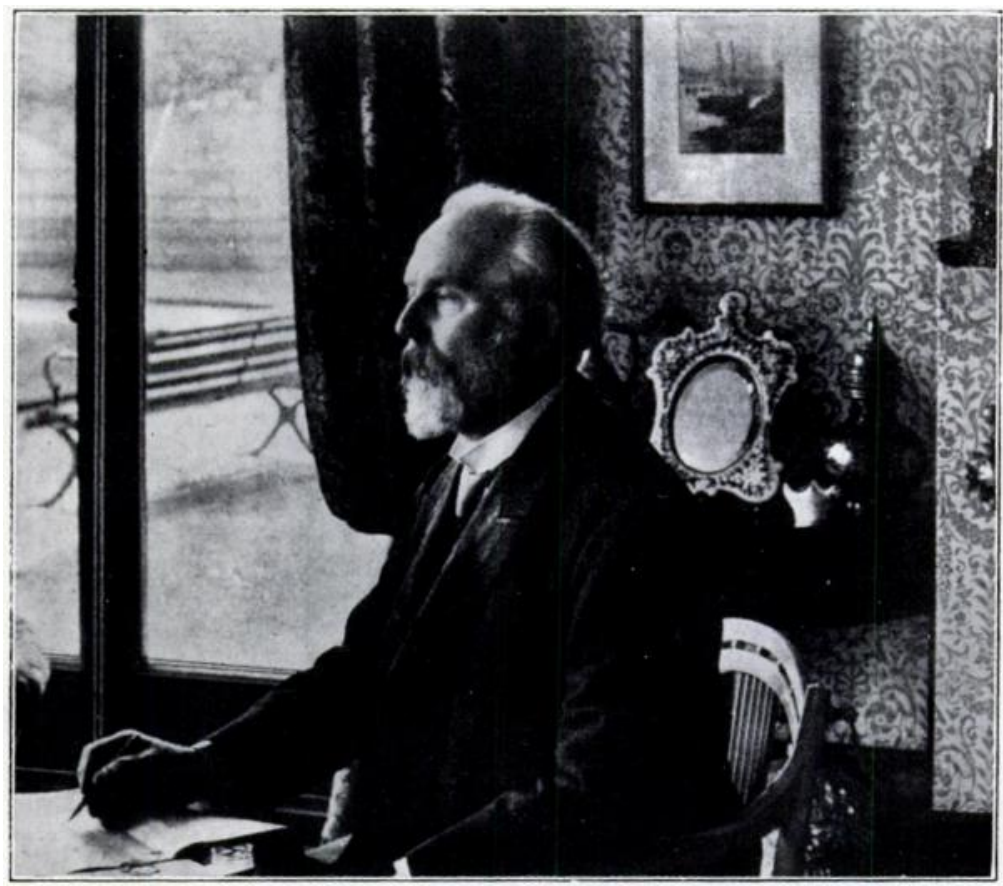

George E. Shettleworth, M.D.

Born November 16,1842 .

Died May 28, 1928.
Ordinary Member since 1877 . 


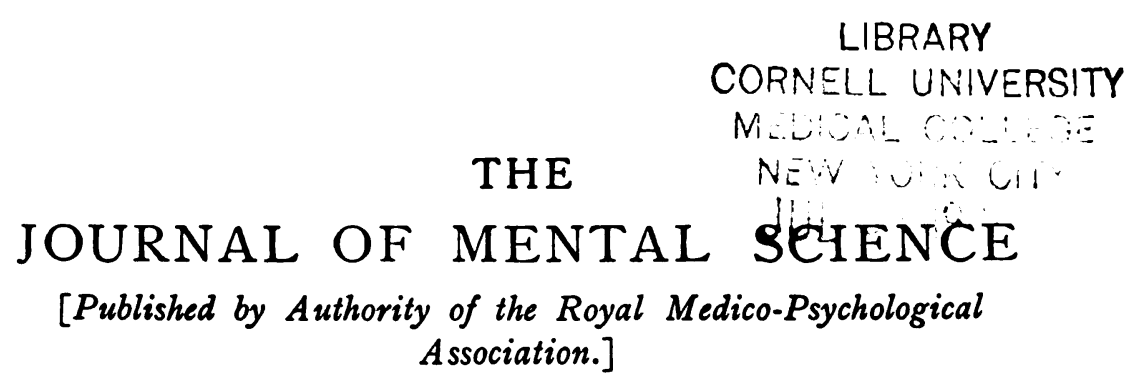

No. $309\left[\begin{array}{c}\text { NEW SERIEs } \\ \text { No. } 273 .\end{array}\right] \quad$ APRIL, 1929.

VoL. LXXV.

GEORGE EDWARD SHUTTLEWORTH, B.A. (HoNs.) LOND., M.D.HEIDELB., L.S.A., M.R.C.S.ENG.,

Fellow of King's College, London.

An Appreciation by Sir Robert Armstrong-Jones, C.B.E., D.Sc., M.D., F.R.C.P.

IT is especially befitting that our Journal should express its appreciation of the great services rendered by the late Dr. Shuttleworth to the welfare of the mentally afflicted and to those who tend them.

He was born on November 16, I842, at Edgbaston, and his long and useful life of 86 years is the history of the care of the feebleminded in this country. It was his skilful and expert guidance which secured for them the first separate legislative enactment, viz., the Idiots Act, I886, since replaced by the Mental Deficiency Act, I913, and its subsequent amending Acts. This Act first made it possible to place mentally defective children under special educative methods of training, and it also for the first time distinguished the care of the weak-minded from that of the insane. By its authority it was no longer necessary to describe backward children as lunatics or persons of unsound mind in the medical certificate-an injustice to them and a deep and cruel wrong to their parents and guardians.

The life of Shuttleworth may also be described as the period of history covered by the pioneer establishments in this work, the Royal Earlswood Institution, then the Earlswood Asylum, and the Royal Eastern Counties Institution, then Essex House, first founded in 1848 , at Park House, Highgate, through the efforts of that noble and large-hearted divine Dr. Andrew Reed.

Dr. Shuttleworth's first appointment in mental diseases was as Assistant Medical Officer to Earlswood, then under the superintendence of Dr. G. W. Grabham (afterwards Inspector of Asylums 
and Hospitals in New Zealand, and a brother of the well-known Dr. Michael Grabham, of Madeira), and the present writer in later years was fortunate in being the successor to Dr. Grabham and Dr. Shuttleworth.

From Earlswood Dr. Shuttleworth was promoted to become the first Medical Superintendent of the newly-founded Royal Albert Institution at Lancaster, where for 23 years he carried on the traditions of Earlswood. It was a Lancaster man, Mr. Samuel Gaskell, F.R.C.S. (in whose memory the Gaskell Gold Medal and Prize were founded), Resident Surgeon and Superintendent of the Lancaster County Asylum - and afterwards a Lunacy Commissioner -who was the originator of the care of the mentally defective in this country, for in 1847 he contributed three articles to what was then called Chambers's Fournal, calling attention to the work carried on by Séguin at Bicêtre for the defective, and urging that the same guiding principles should be adopted in England. This led through the Earl of Shaftesbury-the great philanthropist and "friend of the insane"- to the first constructive policy in this direction. It was Dr. Shuttleworth's life-work to press on with success, earnestness and expert knowledge towards this great ideal.

Just as the humanity of Pinel and Esquirol in France and the genius of Tuke and Conolly in England created an epoch in the treatment of the insane, so it may be claimed the teaching of Séguin in France and America, Shuttleworth in England and Madame Montessori in Italy also created a new departure in the care of the mentally defective, and it is not too much to say that the first modern principles in the education of the backward child were promoted and pursued by Shuttleworth. It is to his influence that "special" schools were instituted for subnormal children, and to him in a great measure that we are indebted for their subsequent success.

After twenty-three years as head of the Royal Albert Institution, Dr. Shuttleworth moved to London, where his great knowledge and wide experience of mental defect soon brought him into fame as a reliable consulting physician and a recognized authority on the education, training and care of the feeble-minded. It is the writer's experience in his official visits that the great help, sympathy and expert advice given by Dr. Shuttleworth are not infrequently referred to with gratitude and affection, not only by parents and friends who have sought his advice, but also by those who have themselves been under his care, those who, through his help, have gained a measure of economic independence and social stability, and are able to take their part in social life or to earn their 
own livelihood in remunerative occupations. He was a great upholder of manual training as an aid to intellectual development, and often pointed out that those with defective articulation and impaired graphic language may yet be most highly endowed with manual dexterity, as the celebrated case of Pullen at Earlswood clearly demonstrated.

Shuttleworth possessed a mind of extraordinary patience and perseverance, and he had "the infinite capacity for taking pains," which enabled him to overcome most obstacles. In action he was deliberate and perhaps slow, but he was impressive and was never ruffled, presenting what has been well described as the "aristocratic calm," and being of the type of "absolute imperturbability," even in a highly charged and conflicting atmosphere. Once his mind was "set," he could not be deflected from his purpose, yet he was large-hearted and generous, and his kindly sympathy was never denied to those who sought his help.

Shuttleworth may be well described as indefatigable. He was a worker all his life, and to the last he was keen to follow up investigation and research into mental problems. He had the advantage of an unusually sound early training at King's College, London, of which he was a Fellow and Hon. Associate, for he graduated B.A. with honours in physiology at London University before taking up his medical career-an exception then as now at this University - and his writings in consequence always showed a studied diction.

He contributed extensively to the literature of his special branch, yet he had many interests and diversions outside his purely professional work. He took an active part in ambulance work, and was an Honorary Associate of the Order of St. John of Jerusalem. He served upon many Boards, Councils and Committees, and he was a member of the Departmental Committee of the Board of Education, upon whose report the Elementary Education Act (Defective and Epileptic Children) was framed and passed in 1909.

He was the greatest friend of the mental nurse, and for years he undertook (with his friend and secretary Major Bargrave Wilson) the laborious task of organizing the Asylum Workers' Association, whose interesting little journal he edited; as a small tribute of acknowledgment for his devotion a presentation was made to him by its members. In no previous account of Dr. Shuttleworth's life have his great services to asylum workers been referred to, viz., in promoting the Act which entitled them to receive pensions. Yet this was his greatest public work.

It may be recalled that through the efforts and interest of the distinguished ophthalmic surgeon, Sir William J. Collins-an 
Honorary Member of our Association and formerly Chairman of the London County Council-the Asylums Officers' Superannuation Bill became law in 1909. This is an Act for which all who have spent their lives in the care of the mentally afflicted must be deeply grateful. Formerly pension for long and meritorious service was an act of grace, and bestowal was within the discretion of the Visiting Committee of each asylum, but Sir William Collins considered that faithful public services should be adequately recog. nized as a matter of right, and his views were, after much discussion, accepted by the Legislature. The part that $\mathrm{Dr}$. Shuttleworth played in this work is best described by the following words in which Sir William Collins himself very generously expressed his appreciation :

"When I introduced the Asylums Officers' Superannuation Bill in the Commons in 1909 and piloted it through all its stages in that House, no one could have had a more active coadjutor or a more resourceful "lobbyist" than I had in Dr. Shuttleworth. Whenever the Bill was on the agenda, and all through the Committee stage, he was in attendance and available for counsel and suggestions.

"When, to secure its passage in the House on the Report stage, I had to accept certain amendments, I reassured him that " in another place" matters could be put right; and in the Lords Dr. Shuttleworth rendered similar aid to Lord Monk Bretton, who kindly shepherded it there.

"Lastly, on the return of the Bill to the Commons with certain financial amendments which transgressed the prerogative of the Commons, I remember Dr. Shuttleworth's eager anxiety as he sat in the front row of the gallery, when, after I I o'clock, I moved and carried, time after time, ' that this House doth agree with the Lords in the said amendment,' thus waiving the Commons' rights in regard to money Bills.

"It is not too much to say that but for Dr. Shuttleworth's vigilance, energy and all-round knowledge of the subject, the Asylums Officers' Superannuation Bill, 1909, would never have reached the Statute Book."

His widow is the daughter of the late Henry Hadwen, of Lancaster, and was a sister of the late Mrs. Fletcher Beach. A son in the Indian Civil Service and a daughter share the loss of a man who loved his home, and of a father who always felt a deep affection for his family.

Dr. Shuttleworth was one of the oldest members of our Association which is the poorer by the loss of this great man. 
Mr. William Morgan, formerly Clerk and Steward to the West Ham Mental Hospital, in a letter to Sir Robert, writes :

"From a sense of duty and with a sincere desire to pay a tribute of profound respect to his memory I will endeavour to comply with your request for a few recollections of the late Dr. Shuttleworth.

"From I9OI until I9II it was my privilege to be in close and constant touch with him, chiefly in connection with the interests of the Asylum Workers' Association, of which I became, by his wishes and encouragement, a fairly active member. On my first acquaintance with him I was greatly impressed by his zeal for the welfare of the mental hospital worker, and it was therefore only natural that I should catch his enthusiasm and do what I could to support him. Only a few of us can have realized the extent of the work which he carried on for a great many years as Secretary of this Association and as Editor of the Asylum Neres. He had to deal oftentimes with a heavy mail-bag, but he was ever attentive and considerate to his numerous correspondents, always giving them the fullest of any information required. It was inexplicable to me how he found time to deal with it all, and why he should have worked so assiduously and made so many sacrifices for the benefit of others without any hope of fee or reward. And when one remembers that writing was to him a slow and painful business, it is truly wonderful that he was able to get through so much, for he had many other interests and activities besides those pertaining to the Asylum service. For years Dr. Shuttleworth and others had struggled on with various schemes to get assured pensions for asylum workers. It often seemed as if we were ploughing the sands, for in the absence of Government support we could not make any appreciable progress. Still he kept plodding on, patiently, and with a great optimism, until eventually he made his great achievement of discovering Sir William Collins and prevailing upon him to become President of the Association. Then came far greater activity. Various conflicting interests within the asylum service had to be reconciled; the sympathy and support of public men secured; a practical Bill on a contributory basis had to be prepared, and evidence had to be submitted to the Select Committee. In these matters Dr. Shuttleworth's wisdom and tact were prominent. The Bill was pushed through Parliament under Sir William's skilful generalship in that memorable session of 1909. All ranks in the service were naturally delighted at the result, and grateful. A few-only a very few-dared to criticize, but they were among the foremost to fight for the preservation of the Act when, about two years ago, a suggestion was officially made for replacing it by some other Act. 
"Everyone in the mental hospital service to-day has reason to be thankful for the existence of such a wise and beneficent Act, but as time goes on those who can remember the energy and sacrifice that brought it about are getting fewer and fewer.

"In saying so much about that Act, therefore, I need not make any excuse, for no tribute to Dr. Shuttleworth's memory would be complete without reference to the great part he played in this matter, and it is only fitting that we should place on record again our sense of gratitude to him.

"Truly one can say that to know him was to love him, for he was always so kind and considerate, without an atom of malice, sham or insincerity in his nature. In all my experience I have never met a more kind-hearted man.

"In closing I would like to make an appreciative reference to the kind and charming lady, Mrs. Shuttleworth, who, by her cheerful devotion, helped him so much in all the good work that he undertook."

Miss Bertha James, the Hon. Secretary of the Society of the Crown of Our Lord (to help mental invalids), in a letter to Sir Robert, writes :

"It was in 1895 that in seeking for advice how best to promote work for the mentally deficient I was told by a high authority to write to Dr. Shuttleworth as 'the best man in England' on the subject. I wrote. He at once responded and introduced me with two friends to various institutions abroad. We were received royally just because he had won there (and everywhere he went) sincere esteem for his professional and personal qualities. Since then, after invaluable help in starting small private schools and homes, we have had reason to be grateful to him in all our efforts to help mental invalids. Not only to us did he give advice, but also to anyone who appealed for help, and in so hidden and modest a way that few realized that they were being aided by a good physician who had moulded his life on that of his great Exemplar, and had built up traditions by which 'the work' still lives and will live."

Dr. Theo. B. Hyslop writes:

"Having known Dr. Shuttleworth for more than forty years, and having worked with him at Lancaster, I have entertained for him the deepest respect and affection. He was always a great enthusiast in his work, a most assiduous and careful student of the problems of mental deficiency, and throughout our long acquaintance he was ever a cordial friend and colleague. His knowledge of his subject was very deep and extensive, and one felt that 
his clinical experience and his wide grasp of the significance of various symptoms were unequalled. His gentleness and subtle sense of humour made him a most charming and agreeable friend. His influence was all for the good."

Dr. H. Wolseley-Lewis writes :

"As I remember him on the Parliamentary Committee he was hard-working and painstaking; he knew his subject from $A$ to $Z$, his subject being the Asylum Workers' Association, of which he was the Honorary Secretary. He had high ideals, and shared with some of us the hope that mental nurses might be welded into a powerful association on professional lines, and it was a great blow to him when the Asylum Workers' Association went smash. His great work was the promotion of the Asylums Officers' Superannuation Act, I909. He inspired the whole movement, and most unselfishly devoted himself body and soul to the cause of his fellow-workers. He was indefatigable in his efforts, and spent much time in 'lobbying' members of Parliament and convincing them of the justice of his cause. Belief in the righteousness of his cause rather than his eloquence brought the matter, after many years of strenuous work, to a satisfactory conclusion. The humblest of men, he did what he did because he believed it to be right, and not in order to be seen and applauded of men."

\section{Editors' Notes.}

Dr. G. E. Shuttleworth was educated at the Philological and City of London Schools and afterwards at King's College, London.

From 1870-1893: Medical Superintendent of the Royal Albert Institution.

From 1899-1901: Medical Examiner of Defective Children to the London School Board.

From I901-5: Medical Expert to Rochester House Institution for Improvable Imbeciles.

From 1900-10: Consulting Medical Officer, National Association for Feebleminded.

Other posts: Medical Officer for Schools for Mentally Defective Children, Willesden Education Committee; Member of the Departmental Committee, Board of Education, which gave rise to the Elementary Education (Defective and Epileptic Children) Act of 1899.

He was for years on the Council and Parliamentary Committee of the Royal Medico-Psychological Association.

His British Medical Association activities included : Member of Council, 18991903; Member of the Parliamentary Committee; President of the Lancashire and Cheshire Branch of the Association ; Vice-President of the Hampstead Division and Secretary $188_{3}$, and Vice-President in 1885 and 1906 of the Section of Psychology.

Principal Publications.-Mentally Deficient Children: Their Treatment and Training, 1895, fifth edition, 1922, and articles in the Encyclopadia Britannica, Allbutt's New System of Medicine, Hack Tuke's Dictionary of Psychological Medicine, Teachers' Encyclopadia and Encyclopadia of Education on Idiocy, Imbecility, and Mentally Defective and Backward Children.

He died at Hampstead on May 28, 1928, and was interred at All Saints' Church, Hertford. 